\title{
Azospirillum spp. from native forage grasses in Brazilian Pantanal floodplain: biodiversity and plant growth promotion potential
}

\author{
Mayara S. T. Souza ${ }^{1,6} \cdot$ Valter A. de Baura ${ }^{1}$ Sandra A. Santos ${ }^{2}$. \\ Paulo Ivan Fernandes-Júnior ${ }^{3}$ Fábio B. Reis Junior ${ }^{4} \cdot$ Maria Rita Marques $^{6}$ • \\ Gecele Matos Paggi ${ }^{5,6} \cdot$ Marivaine da Silva Brasil ${ }^{5}$
}

Received: 14 October 2016 / Accepted: 23 March 2017 / Published online: 29 March 2017

(C) Springer Science+Business Media Dordrecht 2017

\begin{abstract}
A sustainable alternative to improve yield and the nutritive value of forage is the use of plant growthpromoting bacteria (PGPB) that release nutrients, synthesize plant hormones and protect against phytopathogens (among other mechanisms). Azospirillum genus is considered an important PGPB, due to the beneficial effects observed when inoculated in several plants. The aim of this study was to evaluate the diversity of new Azospirillum isolates and select bacteria according to the plant growth promotion ability in three forage species from the Brazilian Pantanal floodplain: Axonopus purpusii, Hymenachne amplexicaulis and Mesosetum chaseae. The identification of bacterial isolates was performed using specific primers for Azospirillum in PCR reactions and partial sequencing of the $16 \mathrm{~S}$ rRNA and nifH genes. The isolates were evaluated in vitro considering biological nitrogen fixation (BNF) and
\end{abstract}

Marivaine da Silva Brasil

marivaine.brasil@ufms.br

1 Programa de Pós-Graduação em Ciências, Bioquímica, Setor de Ciências Biológicas, Universidade Federal do Paraná, Av. Cel. Francisco H. dos Santos, s/n, Jardim das Américas, Curitiba, PR, Brazil

2 Embrapa Pantanal, Rua 21 de Setembro, no. 1.880, 79320-900 Corumbá, MS, Brazil

3 Embrapa Semiárido, BR 428, Km 152, 56302-970 Petrolina, PE, Brazil

4 Embrapa Cerrados, BR 020, Km 18, Planaltina, 73310-970 Brasília, DF, Brazil

5 Ciências Biológicas, Campus do Pantanal, Universidade Federal de Mato Grosso do Sul, Av. Rio Branco, 1270 Universitário, 79304-902 Corumbá, MS, Brazil

6 Programa de Pós-Graduação em Biologia Vegetal, Centro de Ciências Biológicas e da Saúde, Universidade Federal de Mato Grosso do Sul, 79070-900 Campo Grande, MS, Brazil indole-3-acetic acid (IAA) production. Based on the results of BNF and IAA, selected isolates and two reference strains were tested by inoculation. At 31 days after planting the plant height, shoot dry matter, shoot protein content and root volume were evaluated. All isolates were able to fix nitrogen and produce IAA, with values ranging from 25.86 to $51.26 \mathrm{mg} \mathrm{N} \mathrm{mL}^{-1}$ and $107-1038 \mu \mathrm{mol} \mathrm{L}^{-1}$, respectively. The inoculation of $H$. amplexicaulis and A. purpusii increased root volume and shoot dry matter. There were positive effects of Azospirillum inoculation on Mesosetum chaseae regarding plant height, shoot dry matter and root volume. Isolates MAY1, MAY3 and MAY12 were considered promising for subsequent inoculation studies in field conditions.

Keywords Azospirillum brasilense - Biological nitrogen fixation - Diazotrophic bacteria - Indole-3-acetic acid ·

Inoculant

\section{Introduction}

The Brazilian Pantanal is a continuous sedimentary plain, formed 1000 years ago with the uplift of the Andes. It is a part of the Paraguay River Basin, covering the Brazilian states of Mato Grosso (35\%) and Mato Grosso do Sul (65\%), with an approximate area of $140,000 \mathrm{~km}^{2}$ and altitude from 80 to $170 \mathrm{~m}$ (Silva and Abdon 1998). One of the main economic activities in Pantanal is cattle ranching, which has been the dominant economic activity and land use in the region for the past two centuries (Seidl et al. 2001). However, the native forage occurring in the large fields presented relatively low values of zootechnical index, due to low productivity and quality of the forage, which is used as pastures (Santos et al. 2011). Furthermore, cattle 
access to forage depends on forage adaptation to flooding (Santos et al. 2011). Among the main native forage consumed by cattle in Pantanal, grasses species such as Axonopus purpusii, Hymenachne amplexicaulis and Mesosetum chaseae are considered "preferred" by livestock and classified as species that present regular level of consumption (Santos et al. 2002). Axonopus purpusii has C4 photosynthetic pathway, is resistant to temporary water submersion but dies when submitted to prolonged flooding (Allem and Valls 1987), being considered "preferred" and a key species for management plans of native pastures (Santos et al. 2002). The forage H. amplexicaulis is a semi aquatic plant with C3 photosynthetic pathway, native from Central and South America (Silva et al. 2012), occurring in soil flooded for long time period (Agriculture and Resource Management Council of Australia and New Zealand 2000). The species has high digestibility due to the lower presence of fibrovascular structures than other forage species (Santos et al. 2002). Mesosetum chaseae is a perennial Poaceae with a C4 photosynthetic pathway, drought tolerant and widely distributed in Pantanal region. This plant has high productivity, cattle acceptability, being a species with potential for cultivation in higher and not flooded areas, with low fertility (Santos et al. 2011).

In Brazil, the main studies on isolation and identification of diazotrophic bacteria in forage were developed between the 1960s and 1980s. These researches observed considerable contribution of the biological nitrogen fixation (BNF). Among these studies, Boddey et al. (1983), using the $\mathrm{N}^{15}$ isotopic dilution technique, demonstrated a BNF contribution of $10 \%$ for the plant $\mathrm{N}\left(20 \mathrm{~kg} \mathrm{ha}^{-1}\right.$ year $\left.^{-1}\right)$ in Paspalum notatum cv. batatais. In 1986, Boddey and Victoria (1986), using the same technique, observed for Urochloa humidicola and $U$. decumbens, 30-40\% of increase for the accumulated $\mathrm{N}$ using BNF. Another study with these same species showed a BNF contribution of up to $42 \%$ for the plant N (Silva et al. 2010). Lately, Morais et al. (2012) studying the contribution of BNF in different Pennisetum purpureum genotypes, observed a BNF contribution of $18-70 \%$ of the $\mathrm{N}$ accumulated by plants, corresponding to 36-132 $\mathrm{kg} \mathrm{N} \mathrm{ha}^{-1}$, respectively. In this context, Azospirillum spp. is one of the most studied diazotrophic bacteria which can be associated with several plant families (Radwan et al. 2005), presenting a wide distribution, being found in soil, roots, leaves and plant stems (Baldani et al. 2014).

Besides BNF, many effects of Azospirillum spp. in plants are assigned to the production of phytohormones and plant growth-promoting substances by bacteria, auxin, cytokinins and gibberellins (Cavallet et al. 2000; Reis Junior et al. 2004). Bashan and Holgin (1997) reported that phytohormones, mainly the indole-3-acetic acid (IAA), produced and excreted by Azospirillum, play an essential role in promoting plant growth, due to higher production of dry matter and nutrient accumulation observed in plants inoculated with these bacteria. Increase in root development by Azospirillum results in an improvement of water and nutrients absorption, thereby increasing the capacity of plant to produce and withstand environmental stresses, such as drought, flood and salinity, resulting in more vigorous and productive plants (Bashan and Holguin 1997; Dobbelaere et al. 2001; Bashan et al. 2004). Barassi et al. (2008) also reported the improvement in photosynthetic parameters of leafs, including increases in chlorophyll content and stomatal conductance, in addition to the production of biomass and plant height. Due to these evidences, more studies regarding BNF and effects of IAA production by diazotrophic bacteria in forage are necessary to understand the role of these microorganisms in promoting plant grow in the particular environment of the Pantanal. Reis Junior et al. (2002) affirm the need of research regarding BNF and diversity of diazotrophic microorganisms in grasses aiming to obtaining strains with plant growth promotion potential. The genus Azospirillum was first defined by Tarrand et al. (1978) after the characterization of Azospirillum brasilense and A. lipoferum. Currently, there are 17 species described and the most studied is A. brasilense, mostly the strain Sp7, which is used in inoculation experiments. This genus exhibits a versatile carbon and nitrogen metabolism, which is an adaptive feature to survive in different environments (Steenhoudt and Vanderleyden 2000).

For the management of forage grasses native from Pantanal, the use of agricultural inputs, particularly nitrogen fertilizers, is nonexistent. The BNF and IAA production by diazotrophic microorganisms associated with plants roots can improve its yield and nutritional value, association that may contribute to the socio-economic development and the maintenance of this agroecosystem. In Pantanal, diazotrophic bacteria from the genera Azospirillum, Herbaspirillum and Burkholderia were isolated from native forage used for cattle feed, such as Axonopus purpusii, Elyonurus muticus, Hymenachne amplexicaulis, Mesosetum chaseae, and Urochloa humidicola (Brasil et al. 2005). Therefore, the aim of this study was to identify and evaluate the diversity of Azospirillum bacteria isolated from Pantanal native forage grasses, and to evaluate the inoculation effects of Azospirillum isolates on Axonopus purpusii, Hymenachne amplexicaulis and Mesosetum chaseae.

\section{Materials and methods}

\section{Origin of isolates and microbial growth conditions}

Putative diazotrophic bacteria were isolated from roots of three Pantanal native forage: $M$. chaseae, A. purpusii and 
H. amplexicaulis (Table 1), from high (free flooding), intermediate (seasonal flooding) and low (intense flooding) altitudinal gradient, respectively. The plants were sampled in March and July of 2008 and in March and August of 2010 at Nhumirim Farm (18 $59^{\prime} \mathrm{S}$ and 56 $36^{\circ} \mathrm{W}$; 4130 hectares), which belongs to the Embrapa Pantanal, and is located in the Nhecolândia sub-region of Pantanal, Corumbá city, Mato Grosso do Sul State, Brazil. For isolation of bacteria, the technical protocols of Baldani et al. (2014) were followed. The bacteria isolates grew in Dygs medium (Rodrigues Neto et al. 1986) for $24 \mathrm{~h}$, under agitation at $100 \mathrm{rpm}$ and $30^{\circ} \mathrm{C}$. Aliquots $20 \mu \mathrm{L}$ were transferred from the culture to $\mathrm{NFb}$ semi-solid medium. After grown for 5 days at $30^{\circ} \mathrm{C}$, the isolates were cultivated in potato solid medium (Baldani et al. 2014) to verify contaminants. This procedure were realized to obtain a pure and viable isolates to continue the experiments.

\section{Genetic identification of bacteria isolates}

\section{Specific primers for Azospirillum}

The DNA of each bacterial isolate and both type strains (Table 1) were extracted using the Pure Link Genomic DNA Mini Kit (Invitrogen). The PCR reactions were conducted according to Shime-Hattori et al. (2011) using the following primers: Az16-A (5'GCGGTAATACGA AGGGGGCK forward sequence) and (5'CTTGTCACC GGCAGTTCCACCAG reverse sequence), with a product size of $646 \mathrm{bp}$. Two strains (A. brasilense-Sp7 and A. lipoferum-Sp59) were used as positive controls and DNA from Bradyrhizobium sp., Ralstonia sp., Burkholderia sp. and Chryseobacterium indologenes were used as negative controls.

\section{Partial sequencing of $16 S$ rRNA and nifH genes}

The 16S rRNA and nifH genes were amplified by PCR in a reaction volume of $25 \mu \mathrm{L}$ under the following conditions: $40 \mathrm{ng}$ of genomic DNA, 10x of Taq DNA polymerase buffer, $1.5 \mathrm{mmol} \mathrm{L}^{-1}$ of $\mathrm{MgCl}_{2}, 0.2 \mathrm{mmol} \mathrm{L}^{-1} \mathrm{dNTP}$, 5.0 pmol L ${ }^{-1}$ of each primer, $1 \mathrm{U}$ of Taq DNA polymerase. The thermocycling conditions were: initial denaturation at $93{ }^{\circ} \mathrm{C}$ for $45 \mathrm{~s} ; 35$ cycles of denaturing at $93^{\circ} \mathrm{C}$ for $45 \mathrm{~s}, 1 \mathrm{~min}$ annealing at $62^{\circ} \mathrm{C}$ for $16 \mathrm{~S}$ rRNA gene or $45 \mathrm{~s}$ at $55^{\circ} \mathrm{C}$ for nifH gene, extension at $72^{\circ} \mathrm{C}$ for $2 \mathrm{~min}$; and final extension at $72^{\circ} \mathrm{C}$ for $5 \mathrm{~min}$. The primers used for $16 \mathrm{~S}$ rRNA gene were Y1f and Y3r or Y1f and 16S805r (Young et al. 1991; Cruz et al. 2001; Soares-Ramos et al. 2003). PolF and PolR primers (Poly et al. 2001) were used for nifH gene. The PCR products were submitted to enzymatic purification using the Thermo Scientific commercial kit. 
Sequencing of amplified fragments were carried out using the BigDye ${ }^{\circledR}$ kit Terminator v3.1 Cycle Sequencing in the automatic sequencer ABI PRISM 3500 Genetic Analyser (Applied Biosystems). The sequences were analyzed using BioEdit software version 7.1.9 (Hall 1999) to verify sequences quality and chimeric origins. The sequences were verified and assembled using the CLC Genomics workbench 65.1 (CLC bio, Aarhus, Denmark) software and compared with Genbank sequences using BLASTn (http:// blast.ncbi.nlm.nih.gov/). All sequences were deposited in GenBank (access number KX618442 to KX618472 for 16S rRNA and KX881787 to KX881817 for nifH).

The new sequences were combined with obtained sequences of $16 \mathrm{~S}$ rRNA and nifH genes from Ribosomal Database Project (http://rdp.cme.msu.edu) and GenBank. The multiple sequence alignments were performed using MUSCLE. The phylogenetic tree was built using the Maximum-Likelihood method and Junkes-Cantor model with 1000 bootstrap replicates with the aid of MEGA 6.0 software (Tamura et al. 2013).

\section{Evaluation of BNF and production of IAA}

The putative nitrogen fixation capacity was evaluated according to the method of Kuss et al. (2007) with the following modifications: a culture medium without inoculation was used as control and the pure cultures were inoculated in Dygs medium for $24 \mathrm{~h}$ at $30^{\circ} \mathrm{C}$. After growth the optical density was adjusted to 0.5 in a spectrophotometer at $600 \mathrm{~nm}$. An amount of $600 \mu \mathrm{L}$ from culture were inoculated in bottles with $10 \mathrm{~mL}$ of $\mathrm{NFb}$ semi-solid medium and incubated at $30^{\circ} \mathrm{C}$ for 5 days. After the bacteria growing, the bottles were frozen until the evaluations.

To lyse cells, the frozen flasks were heated in microwave for $15 \mathrm{~s} ; 4.0 \mathrm{~mL}$ of each solution was added to digestion tubes containing five glass beads, $330 \mathrm{mg}$ of catalytic mix (10.0 g of $\mathrm{NaSO}_{4}: 0.5 \mathrm{~g}$ of $\mathrm{CuSO}_{4} \cdot 5 \mathrm{H}_{2} \mathrm{O}$ ) and $2.0 \mathrm{~mL}$ of $\mathrm{H}_{2} \mathrm{SO}_{4}$. The tubes were heated in digesters blocks for $2 \mathrm{~h}$ at $180^{\circ} \mathrm{C}$ with a gradual increasing in temperature until $400^{\circ} \mathrm{C}$, which was maintained until the mix achieved a green color. We removed the tubes from digesters blocks and when the temperature reduced to $40^{\circ} \mathrm{C}, 2.0 \mathrm{~mL}$ of deionized water was added. For distillation, $6.2 \mathrm{~mL} \mathrm{NaOH}$ $40 \%$ was added in each tube. This solution was then transferred to Erlenmeyer flasks containing $1.24 \mathrm{~mL}$ of boric acid $2 \%$ solution with mixed indicators $(70 \mathrm{mg}$ of methyl red and $100 \mathrm{mg}$ of bromocresol green, both dissolved in $200 \mathrm{~mL}$ methanol). The titration of the samples was carried out with $\mathrm{HCl} 0.01 \mathrm{M}$. To calculate the $\mathrm{N}$ content, the following formula was used: $\% \mathrm{~N}_{2}$ in the sample $=(\mathrm{Sam}-$ ple titer-Blank titer/Sample wt. in $\mathrm{g} \times 1000) \times$ Molarity of $\mathrm{HCl} \times 14 \times 100$. The results were presented in $\mu \mathrm{g} \mathrm{mL} \mathrm{m}^{-1}$ and were submitted to variance analysis and the average compared according to Scott-Knott's test at $5 \%$ of probability.

To confirm the BNF capacity of all bacterial isolates, a quantitative evaluation were realized regarding the nitrogenase activity in semi-solid medium using the Acetylene Reduction Assay (ARA) (Boddey 1987). The bacteria were grown in NFb semi-solid medium as described above. The vials were closed with rubber taps and $5 \mathrm{~mL}$ of air were taken from the vials and replaced by $5 \mathrm{~mL}$ of acetylene. The vials were incubated in the dark for 30 min when an aliquot of the air were taken for the quantification of ethylene by gas chromatography in a Perkin-Elmer GC Auto System. The bacterial isolates that presented the characteristic peak when compared with the injection of pure ethylene were considered as positive (+) in the ARA.

The production of IAA was analyzed according the colorimetric method described by Sarwar and Kremer (1995) with modifications reported by Reis Junior et al. (2004). The pure bacteria cultures were inoculated in $\mathrm{NFb}$ medium containing $0.1 \%$ of $\mathrm{NH}_{4} \mathrm{Cl}$ (without yeast extract, vitamin and bromothymol blue) and incubated for $24 \mathrm{~h}$ at $30^{\circ} \mathrm{C}$. After sufficient time has elapsed for bacterial growth, the optical density was adjusted to 0.5 in a spectrophotometer at $600 \mathrm{~nm}, 2.0 \mathrm{~mL}$ of the suspension added in $28 \mathrm{~mL} \mathrm{NFb}$ medium with $100 \mu \mathrm{g} \mathrm{mL} \mathrm{m}^{-1}$ of filtrated tryptophan. After the optical density $(500 \mathrm{~nm})$ of the cultures was adjusted to approximately $10^{8}$ cells $\mathrm{mL}^{-1}$. Posteriorly, $1.0 \mathrm{~mL}$ of these cultures was centrifuged at $8000 \mathrm{~g}$ for $15 \mathrm{~min} ; 150 \mu \mathrm{L}$ was added to polystyrene plates containing $100 \mu \mathrm{L}$ of Salkowisk reagent $\left(1.0 \mathrm{~mL} \mathrm{FeCl}{ }_{3} \cdot 6 \mathrm{H}_{2} \mathrm{O} 0.5 \mathrm{M}\right.$ in $\left.50 \mathrm{~mL} \mathrm{HClO}_{4} 35 \%\right)$ and incubated in dark at room temperature for $30 \mathrm{~min}$. Positive results were considered when the solution presented a pinkish color and only positive cultures were used to analyze the absorbance in spectrophotometer at $492 \mathrm{~nm}$. The IAA concentration was estimated using a standard curve with known IAA concentration (0, 25, 50, 100, 200, 500, $1000 \mu \mathrm{M})$, according the equation $\mathrm{y}=910.75 \mathrm{x}-0.0975$ $\left(\mathrm{R}^{2}=0.998\right)$. The results were submitted to variance analysis and the average comparison was realized using the Scott-Knott's test at $5 \%$ of probability.

\section{Effects of Azospirillum spp. inoculation on growing forage}

To evaluate the effect of Azospirillum inoculation, a pot experiment was conducted in a greenhouse using soil and seedlings from three forage species, M. chaseae, A. purpussi, H. amplexicaulis, collected in the Nhumirim Farm, Pantanal region, Brazil.

The soil was classified as a hydromorphic Ultisol, with the following chemical characteristics: $\mathrm{pH} 5.3,6.7 \mathrm{mg} \mathrm{L}^{-1}$ $\mathrm{P}, 0.045 \mathrm{cmmol}_{\mathrm{c}} / \mathrm{dm}^{-3} \mathrm{~K}, 0.29 \mathrm{Ca}, 0.07 \mathrm{cmmol}_{\mathrm{c}} / \mathrm{dm}^{-3}$ $\mathrm{Mg}, 0.625 \mathrm{CTC}, 0.425 \mathrm{cmmol}_{\mathrm{c}} / \mathrm{dm}^{-3} \mathrm{SB}$, and $22.07 \%$ 
V. The quantified micronutrients were $2.23 \mathrm{mg} \mathrm{L}^{-1} \mathrm{Cu}$, $319.76 \mathrm{mg} \mathrm{L}^{-1} \mathrm{Fe}, 5.9 \mathrm{mg} \mathrm{L}^{-1} \mathrm{Mn}$, and $2.7 \mathrm{mg} \mathrm{L}^{-1} \mathrm{Zn}$. The granulometry was $32.22 \%$ of coarse sand, $61.23 \%$ of fine sand, $93.45 \%$ of total sand, $5.03 \%$ of silt and $1.52 \%$ of clay. In this soil, the diazotrophic bacteria was also counted previously using NFb medium and Most Probable Number (MPN) tables, according to Baldani et al. (2014) and around $3.0 \times 10^{3}$ cells $\mathrm{g}^{-1}$ of soil was observed.

Pots with $8.0 \mathrm{~L}$ of capacity were filled with six kilograms of sieved soil. For the inoculant production, the Azospirillum isolates were cultivated in Dygs medium for $24 \mathrm{~h}$ at $30^{\circ} \mathrm{C}$ and $150 \mathrm{rpm}$ of agitation. Before inoculation, the seedlings were washed in running water and pruned (roots and stem) to obtain uniform height and volume. A $1.0 \mathrm{~mL}$ suspension containing $10^{9}$ cells $\mathrm{mL}^{-1}$ was inoculated in the roots of seedlings of each selected forage species. The experiment was conducted in a completely randomized block design, with four repetitions and eight treatments; using one as control, without inoculation, and two Azospirillum type strains, Sp7 and Sp59, with other five treatments using different isolates, which were selected based on their total nitrogen and indole-3-acetic acid production.

Plant growth after 31 days of inoculation was evaluated according to plant height, shoot dry matter, total nitrogen, shoot protein content and root volume. For $H$. amplexicauilis, the height from the stem base to the taller apical bud was measured. For M. chaseae and A. purpusii, the height from the start of the stalk until the taller leaf were measured. The root volume was measured by immersing samples in containers of $300 \mathrm{~mL}$ capacity; the volume of water displacement was registered in $\mathrm{cm}^{3}$. The leaves, roots and stems from each treatment/plant were packed into paper bags and dried at $70^{\circ} \mathrm{C}$ for $72 \mathrm{~h}$. Materials were then weighed to determine dry mass. The shoot protein content was calculated from the total nitrogen accumulated in the shoots, assessed by semi-micro Kjedahl method (Liao 1981). The variance analysis of each parameter and when the variance was significant, the Scott-Knott's test at 5\% probability was performed aiming the averages comparison.

\section{Results}

\section{Identification of isolates}

Specific primers for Azospirillum were effective for preliminary identification of the isolates, but the isolates AZM8 and HAI1 did not present amplification. There was amplification for the type strains, Sp7 and Sp59, but not for bacteria from other genus and species used as negative controls, Bradyrhizobium sp., Ralstonia sp., Burkholderia sp., Chryseobacterium indologenes. Most of the isolates presented amplification products with the same size as of type strains. These results are consistent with morphological observations (data not shown). The sequencing of $16 \mathrm{~S}$ rDNA and nifH genes corroborates with the results for specific primers and showed that most of the isolates are closely related with $A$. brasilense and A. formosense (Fig. 1a, b).

\section{Evaluation of BNF and IAA production}

Variation was observed for values of total $\mathrm{N}$ in culture, from 25.86 to $51.26 \mu \mathrm{g} \mathrm{g}^{-1}$ (Table 2). From the thirty analyzed isolates, MAY3 and MAY15 had higher values of total accumulated $\mathrm{N}$, including when compared to with type strains (Table 2). All isolates were able to produce IAA, which varied from 107 to $1038 \mu \mathrm{g} \mathrm{mL}^{-1}$. The higher values were observed for MAY1, MAY3 and MAY12 (Table 2). The isolate MAY25 did not grow in the selective culture medium; therefore, it was not evaluated for these two parameters. The ARA showed that all bacterial isolates presented the nitrogenase activity due to the presence of a single and clear ethylene peak in the chromatogram.

\section{Inoculation effects of Azospirillum spp. on forage}

Regarding the $M$. chaseae species, and analyzing the parameters separately, the results showed that, for plant height, MAY12 isolate was not statistically different when compared to MAY1, MAY3 and MAY8 isolates, which presented higher values than MAY11, Sp7, Sp59 and control. For root volume, isolates MAY1, MAY3, MAY12, and the type strain Sp7 presented no statistical differences, but they differ from control, isolates MAY8, MAY11, and the Sp59 strain. For shoot dry weight, isolate MAY12 was statistically different when compared to others (Fig. 2).

Considering all parameters together, plants of $M$. chaesea inoculated with MAY12 presented higher height, root volume and shoot dry weight when compared to control and the type strains. Inoculation in A. purpusii showed no significant results for plant height and root volume, but for shoot dry weight, MAY12 isolate presented significantly differences when compared to other treatments. In $H$. amplexicaulis, plant height was not different among treatments. For root volume, the treatments MAY1, MAY3 and MAY11 were better than other treatments, without statistical differences among them. For shoot dry weight, the isolates MAY1, MAY3, MAY12 and the type strain Sp7 presented the better results for this species. There was no significant effect of inoculation on the percentage of shoot protein content in the plants' aerial parts. 


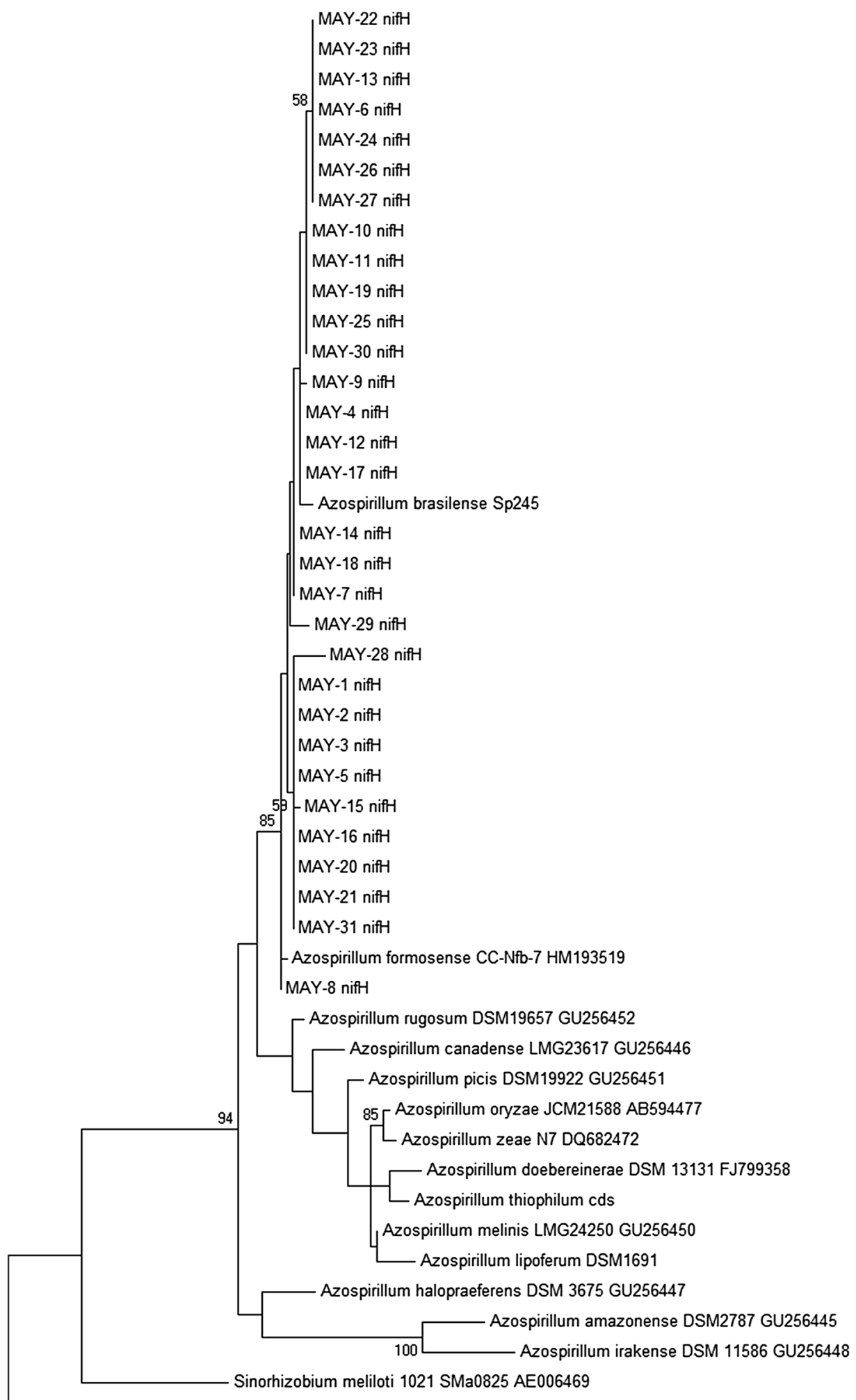

cce 0559 nifH-nitrogenase ironprotein 565791566774 forward

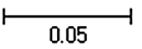

Fig. 1 Phylogenetic tree of 31 isolates from native forage from Pantanal using the maximum-likelihood method and Jukes-Cantor model, based on their nifH (a) and 16S rRNA (b) sequences. Numbers indi- cate the results of the bootstrap analysis with 1000 replicates (bootstrap values above $50 \%$ are not shown) 


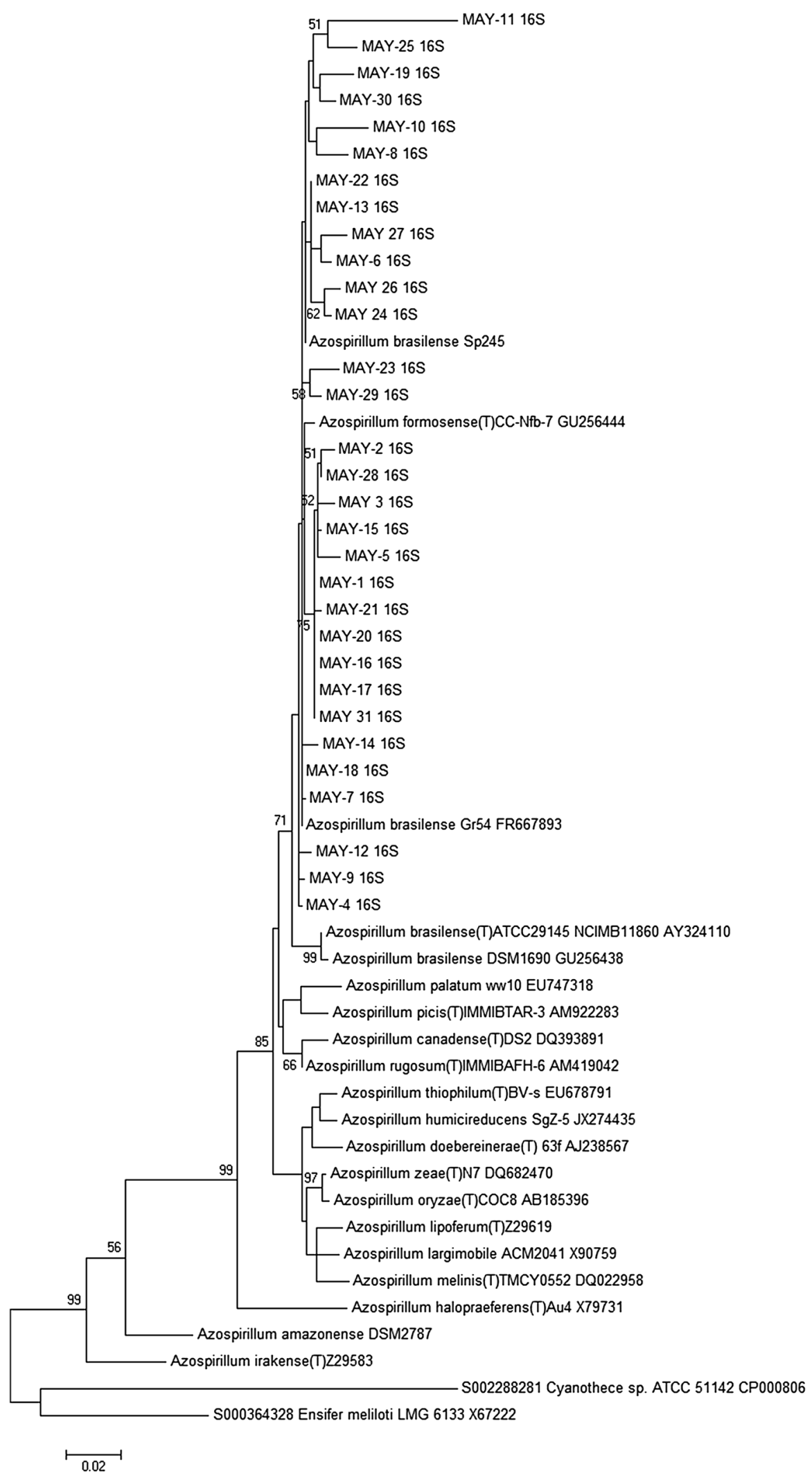

Fig. 1 (continued) 
Table 2 Total nitrogen $(\mathrm{N})$ and production of indole-3-acetic acid (IAA) from different diazotrophic isolates of Azospirillum spp.

\begin{tabular}{|c|c|c|}
\hline Isolate & $\mathrm{N}^{1}\left(\mu \mathrm{g} \mathrm{mL}^{-1}\right)$ & $\operatorname{IAA}^{2}\left(\mu \mathrm{g} \mathrm{mL}^{-1}\right)$ \\
\hline Sp7 & $41.38 \mathrm{~b}$ & $214.70 \mathrm{e}$ \\
\hline Sp59 & $44.53 \mathrm{~b}$ & $141.72 \mathrm{e}$ \\
\hline MAY1 & $43.68 \mathrm{~b}$ & 1038.61 a \\
\hline MAY2 & $36.62 \mathrm{c}$ & $384.24 \mathrm{~d}$ \\
\hline MAY3 & $51.26 \mathbf{a}^{*}$ & $963.27 \mathrm{a}$ \\
\hline MAY4 & $36.15 \mathrm{c}$ & $381.80 \mathrm{~d}$ \\
\hline MAY5 & $34.33 \mathrm{c}$ & $575.95 \mathrm{c}$ \\
\hline MAY6 & $36.10 \mathrm{c}$ & $232.25 \mathrm{e}$ \\
\hline MAY7 & $43.26 \mathrm{~b}$ & $603.72 \mathrm{c}$ \\
\hline MAY8 & $25.86 \mathrm{e}$ & 267.34 e \\
\hline MAY9 & $36.39 \mathrm{c}$ & $712.56 \mathrm{~b}$ \\
\hline MAY10 & $48.14 \mathrm{a}$ & $414.51 \mathrm{~d}$ \\
\hline MAY11 & $37.50 \mathrm{c}$ & $451.63 \mathrm{~d}$ \\
\hline MAY12 & 48.55 a & 1027.68 a \\
\hline MAY13 & $34.62 \mathrm{c}$ & $281.70 \mathrm{e}$ \\
\hline MAY14 & $36.62 \mathrm{c}$ & $136.66 \mathrm{e}$ \\
\hline MAY15 & $50.78 \mathrm{a}$ & $181.19 \mathrm{e}$ \\
\hline MAY16 & $43.20 \mathrm{~b}$ & $802.13 \mathrm{~b}$ \\
\hline MAY17 & $46.67 \mathrm{a}$ & $501.65 \mathrm{~d}$ \\
\hline MAY18 & $41.62 \mathrm{~b}$ & $246.21 \mathrm{e}$ \\
\hline MAY19 & $31.33 \mathrm{~d}$ & $631.51 \mathrm{c}$ \\
\hline MAY20 & $49.14 \mathrm{a}$ & $333.69 \mathrm{~d}$ \\
\hline MAY21 & $37.03 \mathrm{c}$ & $107.02 \mathrm{e}$ \\
\hline MAY22 & $40.09 \mathrm{c}$ & $223.87 \mathrm{e}$ \\
\hline MAY23 & $34.92 \mathrm{c}$ & $296.06 \mathrm{e}$ \\
\hline MAY24 & $39.44 \mathrm{c}$ & $359.89 \mathrm{~d}$ \\
\hline MAY26 & $42.56 \mathrm{~b}$ & $397.76 \mathrm{~d}$ \\
\hline MAY27 & $36.86 \mathrm{c}$ & $754.46 \mathrm{~b}$ \\
\hline MAY28 & $45.85 \mathrm{~b}$ & $151.65 \mathrm{e}$ \\
\hline MAY29 & $44.62 \mathrm{~b}$ & $501.27 \mathrm{~d}$ \\
\hline MAY30 & $38.62 \mathrm{c}$ & $311.46 \mathrm{e}$ \\
\hline MAY31 & $36.68 \mathrm{c}$ & $445.21 \mathrm{~d}$ \\
\hline Mean & 40.28 & 457.23 \\
\hline CV (\%) & 6.80 & 17.50 \\
\hline
\end{tabular}

Type strains and isolates marked in bold were used in inoculation treatments

*Averages with the same letter in the same variable were not different by the Skott-Knott range mean test $(\mathrm{p}<0.05)$

${ }^{1}$ Semisolid $\mathrm{NFb}$ medium

${ }^{2}$ Liquid $\mathrm{NFb}$ medium supplemented with L-tryptophan

\section{Discussion}

Most of the isolates are closely related to A. brasilense and $A$. formosense, which was probably due to the culture medium used for isolation. Besides, it is known that these two species are related concerning the two genic sequences used. The isolates characterized in our study presented BNF and IAA production, showing a potential for plant growing experiments. Regarding the inoculation experiments, the isolate MAY12 showed the best results in terms of shoot dry weight for all forage species, especially for M. chaseae and A. purpusii. Therefore, MAY12 isolate seems to be very interesting for plant growth promotion experiments due to the increasing on shoot dry weight, indicating higher sequestered carbon and forage mass production, fact essential for livestock production.

\section{Identification of Azospirillum spp.}

Currently, an important step in classification of bacteria isolates is the use of molecular techniques and genetic information associated with phenotypic characteristics revealing details about the isolates and enabling polyphasic approaches (Reis et al. 2010). In our approach, after the use of the selective culture medium (for A. brasilense and A. lipoferum), the specific primers identified most of the isolates as Azospirillum spp. (91.2\%). The use of specific primers simplifies the identification and detection of isolates inside rizosphere population and can be used for population ecology studies of a genus (Shime-Hatori et al. 2011). However, for species identification it is necessary to use different genetic techniques such as gene sequencing.

All isolates were closely related to Azospirillum brasilense or A. formosense, regarding $16 \mathrm{~S}$ and nifH genes. However, each gene tree presented different topographies (Fig. 1a, b). According to the A. formosense description (Lin et al. 2012), the $16 \mathrm{~S}$ and nifH genes in this species are highly similar to those of A. brasilense. Moreover, Liu et al. (2012) described that, despite the partial similarity of these genes, there is not a reasonable level of evolutionary synchronism between them, and nifH gene are usually used to define different genus. Besides, Gaby and Buckley (2014) found that due to the genetic divergence of nifH and 16S rRNA genes, they generally produce different results, for example the strains that have high similarity for $16 \mathrm{~S}$ rRNA gene but moderate similarity for nifH gene. According to Wisniewski-Dyé et al. (2012), half of the Azospirillum genome comprises genes from horizontal transfer, including genes related to defense mechanisms, transport, adaptation, and amino acids metabolism, carbohydrates, inorganic ions and secondary metabolites. Also, the genus presented close phylogenetic characteristics when compared to bacteria adapted to aquatic environment, suggesting that the ancestor of these bacteria have already been adapted to these conditions (Wisniewski-Dyé et al. 2012). This can explain the observed divergences on the phylogenetic trees of the present study. 

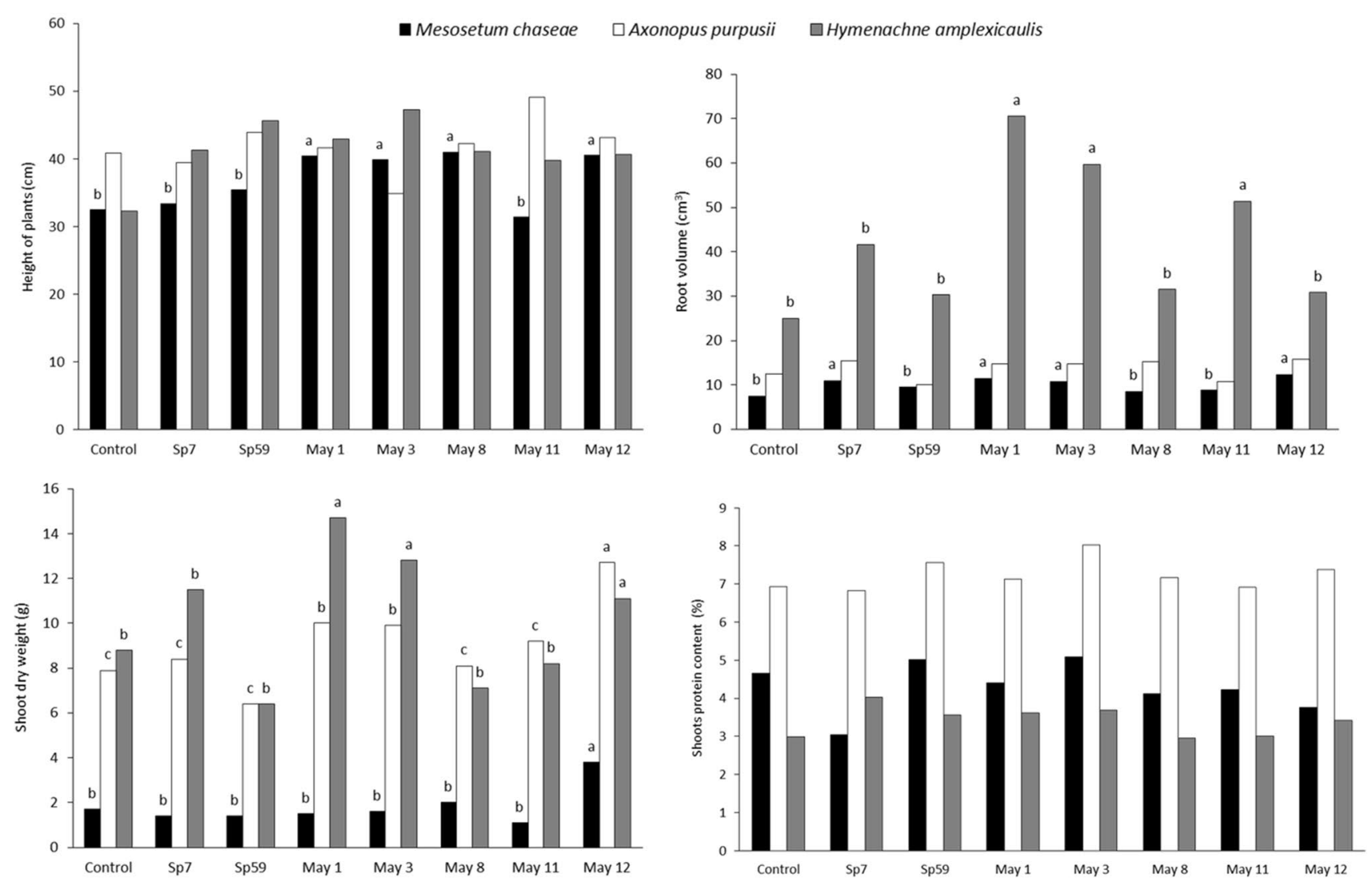

Fig. 2 Means for height, root volume, shoot dry weight and shoots protein content for each Mesosetum chaseae, Axonopus purpusii and Hymenachne amplexicaulis plant inoculated with five native Azospirillum sp. and two reference strains of Azospirillum (A. brasilense

Sp7 and A. lipoferum Sp59). Means with the same letter in each bar, within the same plant species are not different according to the ScottKnott mean range test $(\mathrm{p}<0.05)$. Bars without letters were not statistically different

\section{BNF and IAA production}

Variation was observed for values of total $\mathrm{N}$ in culture medium, from 25.86 to $51.26 \mu \mathrm{g} \mathrm{mL}^{-1}$ (Table 2). Many studies have shown evidences of variations in the nitrogenase activity. Santos et al. (2013) analyzed 25 Azospirillum isolates (from forage) for BNF by acetylene reduction technique and observed results of $26-256 \mathrm{nmol} \mathrm{C}_{2} \mathrm{H}_{4} \mathrm{~h}^{-1}$. Han and New (1998) observed for wheat isolates a variation from 0 to $154.9 \mathrm{nmol}$ of $\mathrm{C}_{2} \mathrm{H}_{4} \mathrm{~h}^{-1}$.

In the present study, among the 30 analyzed isolate, MAY3 and MAY15 presented higher values of $\mathrm{N}$ content in the culture medium (NFb medium) also compared with the strain types (Table 2). The values presented in our results are higher than other studies that used the same technique. Cardoso et al. (2010) reported values of N fixed by Azospirillum in $\mathrm{NFb}$ and LGI medium ranging from 5.18 to $22.8 \mu \mathrm{g} \mathrm{mL}{ }^{-1}$. Kuss et al. (2007) obtained total $\mathrm{N}$ values from 5.56 to $12.99 \mu \mathrm{g} \mathrm{mL}^{-1}$, also in NFb medium for Azospirillum isolated from rice. However, the authors found for the type strains Sp7 and Sp59, values of BNF of 41.09 and $46.82 \mu \mathrm{g} \mathrm{mL}^{-1}$, respectively, similar to the present

study (Table 2). Moreover, Fernandes-Junior et al. (2015) observed values of total $\mathrm{N}$ in culture medium, from 3.5 to $42 \mu \mathrm{g} \mathrm{mL}^{-1}$, and for Azospirillum brasilense strain Ab-V5, the BNF was $35.0 \mu \mathrm{g} \mathrm{mL}{ }^{-1}$. Kanimozhi and Panneerselvam (2010) found the maximum nitrogen fixing value of $15.6 \mu \mathrm{g} \mathrm{mL}^{-1}$ for Azospirillum isolated from Indian soil and for $A$. brasilense the values founded was only $3.3 \mu \mathrm{g} \mathrm{mL}{ }^{-1}$. Although, Azospirillum spp. have the ability to fix nitrogen, freely in the soil or in association with plant roots, the role of BNF in promoting plant growth have not been well elucidated and reported levels of nitrogen fixation provide little or no contribution to the plant's overall nitrogen demand (Pankievicz et al. 2015). However, field studies with wild grass species suggested that BNF can provide $30 \%$ or more of the plant's nitrogen demand (Boddey and Victoria 1986; Morais et al. 2012), attesting the promise of this approach.

On average, the concentration of IAA (mean $=457.23 \mu \mathrm{g} \mathrm{mL}^{-1}$ ) produced by isolates was higher than that observed for type strains Sp7 and Sp59 (Table 2), and higher than the values reported by other studies for Azospirillum. For example, Radwan et al. (2005) observed for Azospirillum strains a production from 300 to $500 \mu \mathrm{M}$ 
of IAA, and Mascarua-Esparza et al. (1988) detected values from 205 to $428 \mu \mathrm{M}$ for A. brasilense and 28.54-97.03 $\mu \mathrm{M}$ for A. lipoferum. Crozier et al. (1988), evaluating IAA production in the same species, reported values from 7.99 to $140.97 \mu \mathrm{M}$ for $A$. brasilense and $0-85.9 \mu \mathrm{M}$ for $A$. lipoferum. Reis Junior et al. (2004) showed that $A$. amazonense, associated with Urocloa spp., produced from 35 to $110 \mu \mathrm{M}$ of IAA. Cardoso et al. (2010) found that Azospirillum strains isolated from rice produced from 5.67 to $119.72 \mu \mathrm{g}$ IAA $\mathrm{mL}^{-1}$. In a recent study conducted by Silva et al. (2013), isolates from Urochloa brizanta roots produced IAA from 0.39 to $195 \mu \mathrm{g}$ IAA $\mathrm{mL}^{-1}$. The type strain Sp7 used in the present study produced higher amounts of IAA than the strain Sp59 (Table 2), corroborating with results observed by Radwan et al. (2005). Is remarkably that our isolates produced higher amounts of IAA, from 107.02 to $1027.70 \mu \mathrm{g}$ IAA $\mathrm{mL}^{-1}$ (Table 2). These results are important since the IAA production by diazotrophic bacteria may positively influence plant grow (Bashan et al. 2014; Yasmin et al. 2007; Vasconcellos et al. 2010).

The main effect of IAA is to promote root and shoot growing, throughout cell division and differentiation on meristematic tissues, which depends directly on hormone concentration. Also, according to Pedraza and Diaz Ricci (2012), the quantity of IAA produced by bacteria strains depends on several factors, for example, the bacteria species and the culture medium conditions (presence or absence of the L-tryptophan precursor, oxidation, $\mathrm{pH}$ and bacterial growth stage), that can influence the production of the vegetal hormone. The isolates of our study are from native forage from different elevation gradient in Pantanal, where the soil presents low fertility under constant hydric stress due to full river system from dry soil to flooded soil (Brasil et al. 2016). These conditions may favor genetic adaptation of the isolates, which had high capacity of in vitro production of IAA. According to Ona et al. (2005), IAA is produced under stress conditions, such as low carbon and oxygen concentration, developing different mechanism for adaptation in these bacteria (Scholoter et al. 2000).

\section{Plant growth promotion by Azospirillum sp. inoculation}

According to the presented results, no differences in shoot protein content considering all inoculation treatments (Fig. 2) was observed. This result can be due to the short time of inoculation that shoots protein content was evaluated: 30 days; Brasil et al. (2005) reported significant levels of $\mathrm{N}$ content after 90 days of inoculation. Likewise, according to Pankievicz et al. (2015), the level of nitrogen fixation would provide little or no contribution to the plant's overall nitrogen demand. Regarding plant growth, an increasing between 25 and 60\% (data not shown) in shoot dry weight was observed, for isolates MAY1, MAY3 and
MAY12 (Fig. 2). These results corroborate with data from Lana et al. (2012), which showed that Azospirillum brasilense inoculation in maize, in absence of nitrogen fertilization, provided an increase of $7.2 \%$ in production of aerial part dry biomass. Ramos et al. (2010) observed an increase of $48 \%$ in aerial part dry matter production and $27 \%$ in dry matter production of roots in plants inoculated with Azospirillum, compared to control. Brasil et al. (2005), studying native forage species from Pantanal, also found higher production (between $45 \%$ ) of shoot dry weight in treatments with Azospirillum inoculation.

Forage species $H$. amplexicaulis and $M$. chaseae presented positive responses to inoculation in relation to root volume, ranging from $50 \%$ to more than $100 \%$ of increase, when inoculated with MAY1, MAY3 and MAY11. For $M$. chaseae the percentage of increase in root volume was approximately $64 \%$, indicating that IAA produced by inoculated bacteria induces root development. Reis Junior et al. (2008) observed increased production of dry root $(14 \%)$ in the treatment inoculated with A. amazonense compared with the non-inoculated control in two maize genotypes. Quadros (2009) also obtained larger root volume in treatments with maize inoculation. Similar results were obtained by Didonet et al. (2003) in ten rice genotypes under inoculation with Azospirillum spp. These authors reported an increase in root length when compared to inoculated plants with the control treatment, and showed that $A$. brasilense induced higher responses in the development of seedlings than A. lipoferum. According to Hungria et al. (2010), the root volume may indicate whether there has been an increase in its growth. The root development increases the area for water and nutrients absorption, consequently increasing plant production capacity and contributing to environmental stresses tolerance, such as salinity, flooding and drought.

Effects of inoculation on plant height were only observed for $M$. chaseae. Similar results were found by Guimarães et al. (2011) in a study with $U$. brizantha inoculated with nine Azospirillum isolates, where higher plants were obtained using AZ02, when compared to control. Ramos et al. (2010) evaluated the growth of corn plants inoculated with Azospirillum lipoferum (BR strain 11084), 30 days after sowing, they observed an increase in plant height. However, the results found by Cavallet et al. (2000) using the commercial product "Graminante", based on Azospirillum brasilense, showed no effects of inoculation on corn plants height.

In terms of protein content, the results of the present study were similar to those reported by Ficagna and Gai (2012) for Tifon 85 forage samples inoculated with $A$. brasilense at 20, 40 and 60 days. Those authors reported that protein content did not vary significantly among inoculated treatments when compared with the nitrogen 
fertilizer treatment. In these cases, the use of bacteria can represent an alternative to nitrogen fertilizers. In another study, the inoculation of $A$. brasilense in seeds of $U$. brizantha resulted in an increase of $5 \%$ in mass production (Silva et al. 2013). However, there was no effect of inoculation on nitrogen content or protein accumulation, similar to the presented results. Although the isolates used in the inoculation experiments did not provide an increase in $\mathrm{N}$ and protein content, the contribution to plant growth was clear, especially for isolates MAY1, MAY3 and MAY12, which may be due to high IAA production. Therefore, these three strains can be considered to have potential for field experiments designed to evaluate the enhancement in plant growth.

The selection of microorganisms with features that increase plant growth is one way to improve high-yield pastures and ecosystem sustainability (Roesch et al. 2007). In this context, the selection of strains with high BNF and IAA production, which are adapted to local conditions, is essential to ensure the growth increment on native forage associated with bacteria.

Funding This study was funded by The Foundation to Support to the Development of Education, Science and Technology of the Mato Grosso do Sul State (FUNDECT/CNPq No. 06/2006 PPP) and the Brazilian National Council for Scientific and Technological Development (CNPq 14/2013).

\section{Compliance with ethical standards}

Conflict of interest The authors declare that they have no conflict of interest.

\section{References}

Agriculture and Resource Management Council of Australia and New Zealand (2000) Weeds of National Significance. Hymenachne (Hymenachne amplexicaulis) Strategic Plan. National Weeds Strategy Executive Committee, p 26

Allem AC, Valls JFM (1987) Recursos Forrageiros Nativos do Pantanal Mato-Grossense. Brasília: EMBRAPA-DDT. Brasília: EMBRAPA-CENARGEN, Documentos, 8, 339

Baldani JI, Reis VM, Videira SS, Boddey LD, Baldani VLD (2014) The art of isolating nitrogen-fixing bacteria from non-leguminous plants using $\mathrm{N}$-free semi-solid media: a practical guide for microbiologists. Plant Soil 384:413-431. doi:10.1007/ s11104-014-2186-6

Barassi CA, Sueldo RJ, Creus CM, Carrozzi LE, Casanovas WM, Pereyra MA (2008) Potencialidad de Azospirillum en optimizar el crecimiento vegetal bajo condiciones advers as. In: Cassán FD, Garcia de Salamone I (eds) Azospirillum sp.: cell physiology, plant interactions and agronomic research in Argentina. Asociación Argentina de Microbiologia, Argentina, pp 49-59

Bashan Y, Holguin G (1997) Azospirillum-plant relationships: environmental and physiological advances (1990-1996). Can J Micorbiol 43:103-121

Bashan Y, Holguin G, De-Bashan LE (2004) Azospirillumplant relations physiological, molecular, agricultural, and environmental advances (1997-2003). Can J Micorbiol 50:521-577. doi:10.1139/W04-035

Bashan Y, de-Bashan LE, Prabhu SR, Hernandez J-P (2014) Advances in plant growth-promoting bacterial inoculant technology: formulations and practical perspectives (1998-2013). Plant Soil 378:1-33. doi:10.1007/s11104-013-1956-x

Boddey RM (1987) Methods for quantification of nitrogen fixation associated with graminae. Cr Rev Plant Sci 6:209-266

Boddey RM, Victoria RL (1986) Estimation of biological nitrogen fixation associated with Brachiaria and Paspalum grasses using $15^{\mathrm{N}}$ labelled organic matter and fertilizer. Plant Soil 90:265-292

Boddey RM, Chalk PM, Victoria RL, Matsui E, Döbereiner J (1983) The use of the $15 \mathrm{~N}$ isotope dilution technique to estimate the contribution of associated biological nitrogen fixation to the nitrogen nutrition of Paspalum notatum cv. batatais. Can J Micorbiol 29:1036-1045

Brasil MS, Baldani JI, Baldani VLD (2005) Ocorrência e diversidade de bactérias diazotróficas associadas a gramíneas forrageiras do Pantanal Sul Matogrossense. R Bras Ci Solo 29:179-190. doi:10.1590/S0100-06832005000200003

Brasil MS, Souza MST, Oliveira IB, Daniel O, Santos SA, Marques MR, Silva WM (2016) Influence of flood areas on the number of diazotrophic bacteria from pasture grasses. Appl Ecol Environ Sci 4(4):84-88. doi:10.12691/aees-4-4-1

Cardoso ICM, Filho OK, Mariotto JR, Miquelutti DJ, Vicente D, Neves, NA (2010) Ocorrência e Diversidade de Bactérias endofíticas do gênero Azospirillum na cultura do arroz irrigado em Santa Catarina. Rev Ciênc Agrovet 9:178-186

Cavallet LE, Pessoa ACS, Helmich JJ, Helmich PR, Ost CF (2000) Produtividade do milho em resposta à aplicação de nitrogênio e inoculação das sementes com Azospirillum spp. Rev Bras Eng Agríc Ambient 4:129-132. doi:10.1590/ S1415-43662000000100024

Crozier A, Arruda P, Jasmim JM, Monteiro AM, Sandberg G (1988) Analysis of indole-3-acetic acid and related indóis in culture medium from Azospirillum lipoferum and Azospirillum brasilense. Appl Environ Microbiol 54:2833-2837

Cruz LM, Souza EM, Weber OB, Baldani JI, Döbereiner J, Pedrosa FO (2001) 16 S ribosomal DNA characterization of nitrogenfixing bacteria isolated from banana (Musa spp.) and pineapple (Ananas comosus (L.) Merril). Appl Environ Microbiol 67:2375-2379. doi:10.1128/AEM.67.5.2375-2379.2001

Didonet AD, Martin-Didonet CCG, Gomes GF (2003) Avaliação de linhagens de arroz de terras altas inoculadas com Azospirillum lipoferum Sp59b e A. brasilense Sp245. EMBRAPA CNPAF, Comunicado Técnico, 69, p 4

Dobbelaere S, Croonrnborghs A, Thys A, Ptacek D, Vanderleyden J, Dutto P, Labandera-Gonzales C, Caballero-Mellado J, Aguirre JF, Kapulnik Y, Brener S, Burdman S, Kadouri D, Sarig S, Okon Y (2001) Responses of agronomically important crops to inoculation with Azospirillum. Aust J Plant Physiol 28:871-879. doi:10.1071/PP01074

Fernandes-Júnior PI, Aidar ST, Morgante CV, Gava CAT, Zilli JE, Souza LSB, Marinho RCN, Nóbrega RSA, Brasil MS, Seido SL, Martins LMV (2015) The resurrection plant Tripogon spicatus (Poaceae) harbors a diversity of plant growth promoting bacteria in northeastern Brazilian Caatinga. R Bras Ci Solo 39:993-1002

Ficagna T, Gai V (2012) Adubação nitrogenada e inoculante de gramínea em tifton 85. Cultivando Saber 5:113-119

Gaby JC, Buckley DH (2014) A comprehensive aligned nifH gene database: a multipurpose tool for studies of nitrogen-fixing bacteria. Database (Oxford) 2014:1-8. doi:10.1093/database/bau001

Guimarães SL, Bonfim-Silva EM, Polizel AC, Campos, DTS (2011) Produção de Capim-marandu inoculado com Azospirillum spp. Enci Bios 7:816-825 
Hall TA (1999) BioEdit: a user-friendly biological sequence alignment editor and analysis program for Windows 95/98/NT. Nucleic Acids Symp 41:95-98

Han SO, New PB (1998) Variation in nitrogen fixing ability among natural isolates ofAzospirillum. Microb Ecol 36:193-201

Hungria M, Campo RJ, Souza E, Pedrosa FO (2010) Inoculation with selected strains of Azospirillum brasilense and A. lipoferum improves yields of maize and wheat in Brazil. Plant Soil 331:413-425. doi:10.1007/s11104-009-0262-0

Kanimozhi K, Panneerselvam A (2010) Studies on isolation and nitrogen fixation ability of Azospirillum spp. isolated from Thanjavur district. Pel Res Lib 1:138-145

Kuss AV, Kuss VV, Lovato T, Flores ML (2007) Fixação de nitrogênio e produção de ácido indolacético in vitro por bactérias diazotróficas endofíticas. Pesq Agropec Bras 42:1459-1465

Lana MC, Dartora J, Marini D, Hann JE (2012) Inoculation with Azospirillum, associated with nitrogen fertilization in maize. Rev Ceres 59:399-405. doi:10.1590/S0034-737X2012000300016

Liao CFH (1981) Devarda alloy method for total nitrogen determination. Soil Sci Soc Am J 45:852-855. doi:10.2136/sssaj1981.0361 $5995004500050005 x$

Lin S-Y, Shen F-T, Young L-S, Zhu Z-L, Chen W-M, Young C-C (2012) Azospirillum formosense sp. nov., a diazotroph from agricultural soil. Int J Syst Evol Microbiol 62:1185-1190. doi:10.1099/ijs.0.030585-0

Liu J, Peng M, Li Y (2012) Phylogenetic diversity of nitrogen-fixing bacteria and the nif $\mathrm{H}$ gene from mangrove rhizosphere soil. Can J Microbiol 58:531-539. doi:10.1139/W2012-016

Mascarua-Esparza MA, Villa-gonzallez R, Caballero-Mellado J (1988) Acetylene reduction and indolacetic acid production by Azospirillum isolates from Cactaceous plants. Plant Soil 106:91-95

Morais RF, Quesada DM, Reis VM, Urquiaga S, Alves BJR, Boddey RM (2012) Contribution of biological nitrogen fixation to Elephant grass (Pennisetum purpureum Schum). Plant Soil 356:2334. doi:10.1007/s11104-011-0944-2

Ona J, Impe J, Prinsen E, Vanderleyden J (2005) Growth and indole3-acetic acid biosynthesis of Azospirillum brasilense Sp245 is environmentally controlled. FEMS Microbiol Lett 246:125-132

Pankievicz VCS, Amaral FP, Santos, KFDN, Agtuca B, Xu Y, Schueller MJ, Arisi ACM, Steffens MBR, Souza E, Pedrosa FO, Stacey G, Ferrieri R (2015) Robust biological nitrogen fixation in a model grass-bacterial association. Plant $\mathrm{J}$ 81:907-919. doi:10.1111/tpj.12777

Pedraza RO, Diaz-Ricci JC (2012) A survey of denitrifying Azospirillum brasilense in two contrasted conditions of the sugarcane cropping region of Tucumán, Argentina. Rev Agron Noroeste Argent 32:23-29

Poly F, Ranjard L, Nazaret S, Gourbie`re F, Monrozier J (2001) Comparison of nifH gene pools in soils and soil microenvironments with contrasting properties. Appl Environ Microbiol 67:22552262. doi:10.1128/AEM.67.5.2255-2262.2001

Quadros PD (2009) Inoculação de Azospirillum spp. em sementes de genótipos de milho cultivados no Rio Grande do Sul. Master Dissertation, Universidade Federal do Rio Grande do Sul, Porto Alegre, $\mathrm{p} 62$

Radwan TEE, Mohamed ZK, Reis VM (2005) Aeração e adição de sais na produção de ácido indolacético por bactérias diazotróficas. Pesq Agropec Bras 40:997-1004. doi:10.1590/ S0100-204X2005001000008

Ramos AS, Santos TMC, Santana TM, Guedes ELF, Montaldo YC (2010) Ação do Azospirillum lipoferum no desenvolvimento de plantas de milho. Rev Verde 5:13-117

Reis, VM, Schawab S, Rouws LFM, Teixeira KRS (2010) Diazotróficos associativos e de vida livre: avanços e aplicações biotecnológicas. In: Figueiredo MVB, Burity HA, Oliveira J P, Silva
Santos CER, Stamford NP (eds) Biotecnologia aplicada à agricultura: textos de apoio e protocolo experimentais. Embrapa Informação Tecnológica, Brasília, pp 215-238

Reis Junior FB (2002) Ecologia e diversidade de bactérias do gênero Azospirillum em associação com pastagens de Brachiaria spp. PhD Theis, Universidade Rural do Rio de Janeiro, Seropédica, p 97

Reis Junior FB, Silva MF, Teixeira KRS, Urquiaga S, Reis VM (2004) Identificação de Azospirillum amazonense associadas à Brachiaria spp., em diferentes épocas e condições de cultivo e produção de fitohormônio pela bactéria. R Bras Ci Solo 28:103-113

Reis Junior FB, Machado CTT, Machado, AT, Sodek L (2008) Inoculação de Azospirillum amazonense em dois genótipos de milho sob diferentes regimes de nitrogênio. R Bras Ci Solo 32:1139-1146

Rodrigues Neto J, Malavolta Júnior VA, Victor O (1986) Meio simples para o isolamento e cultivo de Xanthomonas campestres pv. Citri tipo B. Summa Phytopathol 12:16

Roesch LFW, Quadros PD, Camargo FAO, Triplett EW (2007) Screening of diazotrophic bacteria Azopirillum spp. for nitrogen fixation and auxin production in multiple field sites in southern Brazil. World J Microbiol Biotechnol 23:1377-1383

Santos AS, Costa C, Souza GS, Pott A, Alvarez, JM, Machado SR (2002) Composição Botânica da Dieta de Bovinos em Pastagem Nativa na Sub-Região da Nhecolândia, Pantanal. R Bras Zootec 31:648-1662

Santos AS, Desbiez AL, Crispim SMA, Comastri Filho JA, Abreu UGP, Rodela LG (2011) Natural and cultivated pastures and their use by cattle. In: Junk WJ, Silva CJ, Nunes da Cunha C, Wantzen KM (eds) The Pantanal: ecology, biodiversity and sustainable management of a large neotropical seasonal wetland. Pensoft Publishers, Sofia

Santos MCM, Santos DR, Bakke AO, Bakke IA (2013) Ocorrência e atividade de bactérias diazotróficas em forrageiras cultivadas na Região semiárida no Brasil. Rev Caatinga 26:27-34

Sawar M, Kremer R (1995) Enhanced suppression of plant growth through production of L-tryptophan-derived compounds by deleterious rhizobacteria. Plant Soil 172:261-269

Schloter M, Lebuln M, Heulin T, Hartmann A (2000) Ecology and evolution of bacterial microdiversity. FEMS Microbiol Rev 24:647-660

Seidl AF, Silva JSV, Moraes AS (2001) Cattle ranching and deforestation in the Brazilian Pantanal. Ecolog Econ 36:413-425

Shime-Hattori A, Kobayashi S, Ikeda S, Asano R, Shime H, Shinano $\mathrm{T}$ (2011) A rapid and simple PCR method for identifying isolates of the genus Azospirillum within populations of rhizosphere bacteria. J Appl Microbiol 111:915-924

Silva JSV, Abdon MM (1998) Delimitação do Pantanal brasileiro e suas sub-regiões. Pesq Agropec Bras 33:1703-1711

Silva LLGG, Alves GC, Ribeiro JRA, Urquiaga S, Souto SM, Figueiredo MVB, Burity HA (2010) Fixação biológica de nitrogênio em pastagens com diferentes intensidades de corte. Arch Zootec 59:21-30

Silva KS, Machado SLO, Menezes NL, Urban LJK, Alves MVP (2012) Adequação da metodologia do teste de tetrazólio para sementes de Hymenachne amplexicaulis. Semina 33:1819-1824

Silva MCP, Figueredo AF, Andreote FD, Cardoso EJBN (2013) Plant growth promotiong bacteria in Brachiaria brizantha. World $\mathrm{J}$ Microbiol Biotechnol 29:163-171

Soares-Ramos JRL, Ramos HJO, Cruz LM, Chubatsu LS, Pedrosa FO, Rigo LU, Souza EM (2003) Comparative molecular analysis of Herbaspirillum strains by RAPD, RFLP, and 16S rDNA sequencing. Genet Mol Biol 26:537-543

Steenhoudt O, Vanderleyden J (2000) Azospirillum, a free-living nitrogen-fixing bacterium closely associated with grasses: 
genetic, biochemical and ecological aspects. FEMS Microbiol Rev 42:487-506

Tamura K, Stecher G, Peterson D, Filipski A, Kumar S (2013) MEGA6: molecular evolutionary genetics analysis version 6.0. Mol Biol Evol 30:2725-2729

Tarrand JJ, Krieg NR, Döbereiner J (1978) A taxonomic study of the Spirillum lipoferum group, with descriptions of a new genus, Azospirillum gen. nov. and two species, Azospirillum lipoferum (Beijerinck) comb. nov. and Azospirillum brasilense sp. nov. Can J Micorbiol 24:967-980

Vasconcellos RLF, Silva MCP, Ribeiro CMR, Cardoso EJBN (2010) Isolation and screening for plant growth-promoting (PGP) actinobacteria from Araucaria angustifolia rhizosphere soil. Sci Agric 67:743-746
Wisniewski-Dyé F, Lozano L, Acosta-Cruz E, Borland S, Drogue B, Prigent-Combaret C, Rouy Z, Barbe V, Mendoza HA, González V, Mavingui P (2012) Genome sequence of Azospirillum brasilense CBG497 and comparative analyses of Azospirillum core and accessory genomes provide insight into Niche adaptation. Genes 3:576-602

Yasmin F, Othman R, Saad MS, Sijam K (2007) Screening for beneficial properties of rhizobacteria isolated from sweetpotato rhizosphere. Biotechnology 6:49-52

Young JPW, Downer HL, Eardly BD (1991) Philogeny of photrophic Rhizobium strain BTAi1 by polymerase chain reaction-based sequencing of a 16S rRNA segment. J Bacteriol 173:2271-2277 